\title{
On Not Being Lost in Translation: Creative Strategies to Approach Multiculturalism in Esperanto
}

\begin{abstract}
Abstrakt (Jak nie zaginąć w przekładzie: twórcze strategie podejścia do wielokulturowości w esperancie). W niniejszym artykule przeanalizowano praktyki przekładu na esperanto, język skonstruowany, który liczy już 130 lat i który ma służyć neutralnej komunikacji międzynarodowej. Jednym z praktycznych zastosowań tego pomocniczego języka jest udostępnienie ogólnoświatowej społeczności mówców dzieł z całego świata i z różnych epok. Analizowana jest rola odgrywana przez thumaczenie w rozwoju esperanta oraz w tworzeniu społeczności esperanckiej. Autorka dowodzi, że tłumaczenie na esperanto spełnia kluczową funkcję społeczną i przekazuje wartości wykraczające poza zwykły transfer semantyki. Czyniąc to, stosuje interdyscyplinarną perspektywę i wykorzystuje podejścia z badań translacyjnych, językoznawstwa, antropologii i badań komunikacji międzykulturowej. Umieszczenie tych podejść w dialogu jest korzystne dla lepszego zrozumienia różnych strategii stosowanych przez thumaczy esperanckich w celu uwzględnienia i zrozumienia esperanckiego horyzontu kulturowego.
\end{abstract}

\begin{abstract}
This article examines translation practices into Esperanto, a constructed language with 130 years of existence and which is meant to serve neutral international communication. As such, one of Esperanto's practical applications is to render works from around the world and from different times accessible to a worldwide community of speakers. We analyse the role played by translation in the development of Esperanto and in the creation of an Esperanto community. We argue that translation into Esperanto possesses a key social function and conveys values that go beyond the mere transfer of semantics. In doing so, we apply an interdisciplinary perspective and draw on approaches from translation studies, linguistics, anthropology and intercultural communication studies. Placing these approaches within a dialogue is beneficial for a deeper understanding of the various strategies employed by Esperanto translators in order to accommodate and to inform the Esperanto cultural horizon.
\end{abstract}




\section{Introduction}

Mapping translations into Esperanto gives a glimpse of a sound body of works from around the world and from different times. Esperanto enthusiasts argue that this high translatability is due to the aesthetics of the language and to the fact of Zamenhof being a poet. Apologetics go as far as to say that Esperanto is "naturally predestined to vehiculate and to disseminate the literary works in the future' (Guimarães Rosa, cited in Sartorato 2013), enabling genuine tasting of genres that range from Ukrainian dumy to Japanese haiku and Finnish runi. The fact is, more than 10,000 works have been translated into Esperanto (Janton 1992), a wide range from both a thematical and a stylistical point of view. What is noticeable about Esperanto translators is that they tend to translate from their native language into Esperanto, rather than from Esperanto into their native language. Choosing to write or to translate in Esperanto is influenced by the poet's perception that Esperanto has particular qualities for complex expression (Tonkin 2010). Others express a different view: it is not the intrinsic quality of the target language that makes a good translation, but the translator's creative power, as Janton (1989) argues based on translations of Shakespeare into Esperanto. Whatever the case, translating performs a mediatory function within the community of writersreaders and exerts a formative influence on its aesthetic experience. It validates source texts as 'worth translating', that is, recognizes their literary value, and at the same time it contributes to the creation of this value. The selected works have to be 'culturally' translated, that is, adapted to the horizon of the Esperanto community of readers. Translating is definitely a creative act with political consequences.

Many questions arise in this process: What are the ethical and political dimensions of translation, and what is particular about Esperanto in this framework? How are cultural references constructed? To what extent does translating into Esperanto provide evidence of a committed literature? What kind of aesthete is the Esperanto translator? What are their strategies to illustrate local colour, patina of time and marginal forms of expression? These are legitimate questions to pose when exploring the case of Esperanto, a language that was intended to be easy to learn, and as such, logical, straightforward and thrifty with words. Such qualities recommend it in the automatic translation of languages, whereby Esperanto is assumed to function as a pivot-language (Schubert 1992, Boddington 2004, Gobbo 2015). An eclectic corpus is analysed with a view to revealing these intricacies of translation into Esperanto. The meaning-providing process is explored in the light of the Esperanto culture and its intentions. An introductory overview provides the necessary conceptualisation tools for this analysis. 


\section{Theoretical background}

Proceeding from a general view to the topic of cultural translation, before delving into the Esperanto case, we will take an interdisciplinary approach. We will thereby draw on concepts from translation studies, literature, linguistics, anthropology and intercultural communication studies.

Early translation theories exhorted the translator's invisibility in the text, whereby translation was considered a secondary art. Benjamin's famous theory on the task of the translator (1923) marks a decisive break with this standpoint, by placing the translation as an art in its own right. For him, the significance of a text should be considered in its context, and what should be translated is rather the intention than the information. Benjamin's ideas remain yet sparsely-visited in the following decades and it is not until the late 1970s that the translator's role as a creative subject moves to the spotlight.

After the 1970s, a translative turn emerges, breaking with the binaries of form/ content, signifier/signified, as praised by the theory of the linguistic sign. The deconstructive theories of Derrida (1985), De Man (1986) and Venuti (1995) draw attention to the translator's creativity and active interpretation of the source text. Bhabha's ideas (1994) place the translator in a 'third space', characterised as hybrid and subversive. In the same postcolonialist perspective, Spivak $(1993 ; 2007)$ shows the role of translation in manipulating the image of the colonised and calls for enhancing of the study of minority languages by the ex-colonisers, rather than expecting for translations in the language of power. Enhancing the interdisciplinary debate, Buden and Nowotny (2009) state that interlingual translation implies a specific form of cultural translation, that is, an interaction between individuals who belong to different cultures. Translating is thus a form of cultural transfer, affecting practices, values and representations. Vermeer (1996) argues for a 'crosscultural transfer', whereby the criteria for a good translation rely not only on the linguistic, but also on the cultural abilities of the translator. That is, the translator must be at the same time bilingual and bicultural. The target text is addressed to a specific audience and is driven by a specific purpose (skopos), being thus influenced by the extra-linguistic context. All these theories lead to highlighting new aspects in translation studies: the shift from meaning to the meaning-producing, the subjectivity and agency of the translator, and the interaction between translation and culture.

Translating is also a matter of ethics, since it transforms both the translator and the reader. Pym (2001) considers the translator to carry responsibility in terms of intercultural ethics, in that they should foster cooperation. The ethics of translation imply negotating cultural politics and ideological positioning. For Cheung (2014), the translator assumes identities of mediator, negotiator, ideological gate-keeper and activist. According to her, subjectivity informs the translation into an act of intercultural communication, 'a site for the analysis of cultures in contact, confluence, conflict or contest'. In the same dialogical perspective, Coste (2016) argues that the politics of translation lie in the relations between the cultures concerned by the translational ex- 
change, providing as such an intercultural maidan. Nouss (2005) names this a form of metissage, that is, a textual form in movement and in continuous construction between two languages and two cultures. Meschonnic $(1995 ; 1999 ; 2007)$ calls for a poetics of translating and highlights its ethical and political aspects. He introduces the notion of rhythm, understood as rythm of thought that produces power of expression, and pays special attention to how the meaning of the original text is conveyed: 'more than what a text says, it is what a text does that must be translated'.

We see thus that the translation act possesses specific discoursive values that go beyond a mere transfer of semantics. In order to explore that, let us examine how translation partakes of the Esperanto aesthetico-political configuration by taking into account some of the challenges highlighted by Esperanto translators.

\section{Translating the past}

A first challenge posed by Esperanto's relatively short existence as a language involves the translation of classic literature and antique works. How can a language with only 130 years of existence express diachronic registers? How can it accomodate classic styles through translation? These are questions in which the translator's subjectivity has its word to say, implying a political choice and a historical consciousness. Esperanto translators can here avail themselves of the common property on Esperanto. Since Zamenhof renounced all his rights over the language, Esperanto has become common property of its speakers, who can intervene in the formation of the language, as required by the needs of translation.

The structural fundamentals of Esperanto have changed little since its origin in 1887, but vocabulary, speech patterns and idiomatic expressions developed substantially. Its linguistic evolution was chiefly marked by loanwoards, which enabled it to naturally keep track of new realities. Apart from these changes that occured in the language, some users wanted to provide Esperanto with a history, so as to increase its authority and prestige, or to question the very notion of language evolution. In a provocative-ludic approach, some tried to recreate what should have been the Arcaicam Esperantom or the Mezepoka Esperanto ${ }^{l}$.

Arcaicam Esperantom ('Archaic Esperanto') was invented by the Esperanto writer Manuel Halvelik ${ }^{2}$ in 1969. He used it for translating Romeo and Juliet, ancient aphorisms, the Esperanto anthem, excerpts from Balzac (Les contes drôlatiques), Roman de Renart, Till Eulenspiegel, Mark Twain (A Connecticut Yankee at King Arthur's Court), among others.

1 Not to be confused with Proto-Esperanto, Zamenhof's early project, prior to the version published in1887 in Unua Lingvo.

2 Halvelik created two other varieties of Esperanto, Gavaro ('speak') and Popido ('popular idiom'). 
Mezepoka Esperanto ('Medieval Esperanto') is the fictional creation of the poet Kálmán Kalocsay - 'the Esperanto of The Song of Roland, Vogelweide and Francis of Assisi', discovered on a $12^{\text {th }}$-century parchment in the monastery of Utop. Kalocsay provided this fictitious language with a grammar and a vocabulary (Grammaticu kaj vocabularu antiques mundales lingues Sperantu) and used it in the last chapter of his book Lingvo Stilo Formo (1931) ('Language, Style, Form').

These sociolects are used in reflecting different literary styles and conveying the subtleties of the source language. Both are elaborate versions of Esperanto, constructed by analogy with early phases of Romance languages, with strong Latin traces.

Halvelik (1989) addresses the issue of nonstandard language forms in Esperanto. Albeit rare, different registers are used by Esperanto writers: diatopic ('nationalisms' - interference errors: 'efekto' ('efect') instead of 'efiko'); diachronic (obsolete terms still intelligible but carying a patina of time: 'anaro' ('troop'), 'glitveturilo' ('sleigh'), 'ĉirkaŭmano' ('bracelet'), replaced by 'trupo', 'sledo', respectively 'braceleto'); diastratic (slang words: 'drinki' ('guzzle'), 'kuŝkuŝs!' ('gosh!') ). Halvelik concludes that the existence of levels of speech in Esperanto is only made possible because of its body of literature - no other constructed language has achieved such language variation, and that is because of the lack of sufficiently large communities of writers and readers.

It must be noted that these artificially produced sociolects have only been used in texts produced by an author. Esperanto authors choose their own ways of expressing social difference and temporal difference, which leads to the question of whether this type of language planning is still possible in a planned language that is in use. These linguistic inventions are challenges that concern not only Esperanto, but also 'natural' languages ${ }^{3}$.

But before the invention of these sociolects for literary needs, Esperanto itself was invented through the translation of classic literature. In the early years of Esperanto, Zamenhof was putting it to the test by translating Shakespeare, which significantly informed the emerging language and its literary tradition. Translations of Shakespeare were considered in the $19^{\text {th }}$ century a proof for emerging literary languages. Zamenhof translated Hamlet, which became one of the cornerstones of Esperanto literary tradition. The number of Shakespeare's plays translated into Esperanto increased over the decades to 21. It is thus considered that Shakespaere, along with his translators, played an important role in the development of Esperanto (Auld 1997; Tonkin 2016).

\section{Emerging idioms}

The second challenge that lies ahead Esperanto translated literature is constructing common references. The one sure thing is that finding communalities for a worldwide

3 In an introduction to Interlinguistics, Schubert (1989) draws on an example from Buffa (1987), namely translating the archaic Italian into Finnish, a language whose writing traditions only started in the $16^{\text {th }}$ century. 
community of readers is an extremely ambitious task, in as much as these readers have different linguistic, cultural and literary backgrounds. In doing so, I will consider the translation into Esperanto of Les Aventures de Tintin (La Aventuroj de Tinĉjo), a comic strip originally published in French in 1958 by Hergé and widely translated into many languages. Les Aventures de Tintin is replete with colorful language and culturally embedded French references, which makes it particularly relevant to be analysed as a way of sheding light to these translation paradigms. I also added the English version, with the aim of comparing how the English translator approached the same translation problems ${ }^{4}$.

Let us have a look at the scene in which Tintin dreams that his Chinese friend Chang, who disappeared in a plane crash, is still alive, and shares his hope to the sarcastic Captain Haddock, who then mocks Tintin: 'Moi, j'ai révé de Napoléon, cette nuit : ce n'est pas pour ça que je le crois vivant, moi !' (Table 1) The English translator changes the reference to Napoleon for a figure better known in the Anglo-Saxon world, namely Columbus. The Esperanto translator comes up with a name universally known by Esperantists: Captain Haddock 'dreams' here of Zamenhof.
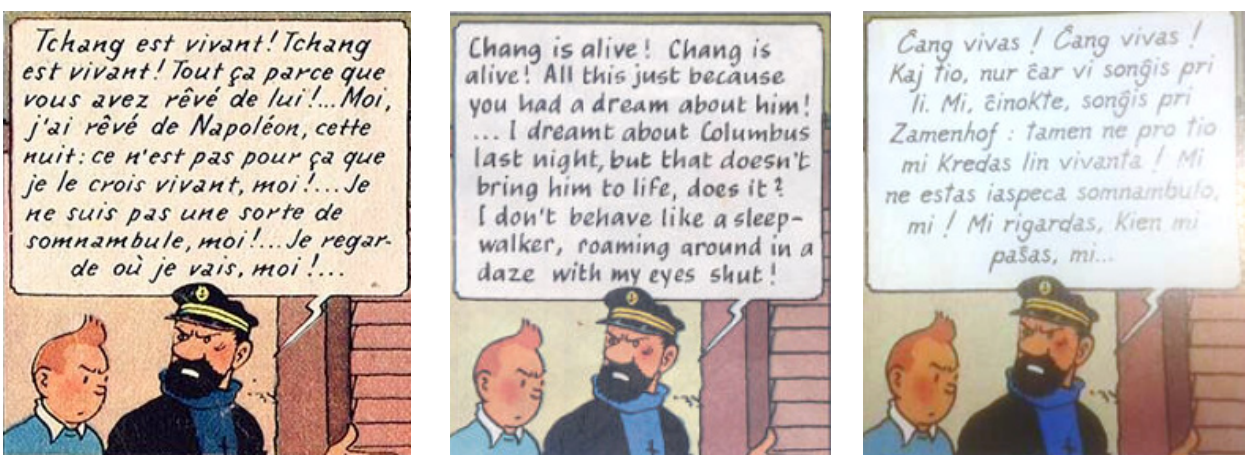

Table 1: Excerpt Tintin in Tibet (fr/en/eo)

Having bumped into some passersby, Captain Haddock explodes with rage: 'Mille milliards de mille sabords de tonnerre de Brest ! vous le faites exprès, bande de bachibouzouks!...' (Table 2) The expression 'tonnerre de Brest' is common in Captain Haddock's vocabulary throughout the comics. It originates in a resemblance between thunder and cannon shots, referring to the shots of the prison of Brest, in Brittany (France). Both English and Esperanto translations cut out the reference to Brest. Another figurative expression in the same panel is 'bachi-bouzouks', meaning at its origins an irregular

4 I used here panels drawn from Tintin au Tibet, 1958 ; Tintin in Tibet, 1962; Tinçjo en Tibeto, 2005. The panels in Table 1 are found on p. 10 and the panels in Table 2 are found on p. 11 . 
soldier of the Ottoman army, or in a secondary sense, an undisciplined person, vagrant. It remained the same in the English translation of Tintin: 'gang of Bashi-bazouks'. The Esperanto translation replaces it with 'Volapukisto' - a speaker of Volapük. Volapük was an artificial language that preceded and competed with Esperanto. Nowadays, the term is used figuratively and means 'nonsense', 'gibberish', 'gobbledegook'. Likewise, Esperantists would never say in Esperanto: 'It sounds like Greek to me'. They would say: 'It sounds like Volapük to me'. Interestingly, there is another language that uses the term 'Volapük', namely Danish, with the same meaning of unintelligible messy language, but without the origin of the term being commonly known by the Danes.
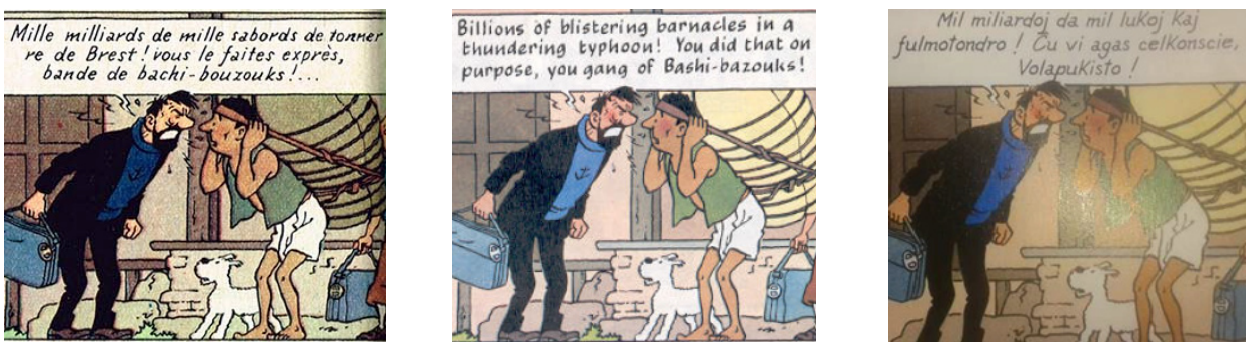

Table 2: Excerpt Tintin in Tibet (fr/en/eo)

These examples illustrate the phenomenon of constructing a cultural community by creating a common framework of references. Not only 'Zamenhof' and 'Volapukisto' are understood by the ordinary Esperantist with a little knowledge of the history of Esperanto movement, but they are understood only by Esperantists. They do not make sense for common readers from other cultural backgrounds. They have become lexicalized terms in Esperanto.

\section{John Doe goes Esperantist}

The third challenging point is linked to the previous one and answers an anthropological question: How does translation inform the Esperanto community, i.e. how does it impact on the shaping of an articulated movement?

Some years ago, I attended the Zamenhof Day in the Cultural Cooperative of Esperantists in Rio de Janeiro. Celebrated on 15 December (Zamenhof's birthday), it is the most important Esperanto event of the year, in which artistic performances and speeches pay a tribute to the language and to its founding father. One of the activities proposed within the programme was a performed translation into Esperanto of the poem E agora, José? First, a few words on the original, in order to understand the context of the Esperanto translation. 
This poem was written by the Brazilian poet Carlos Drummond de Andrade during the Second World War, in 1942, under the dictatorship of Vargas. The Brazilian society was ruled by a military regime who had proclaimed the 'Estado Novo' ('New State'). Drummond's poem was an interrogation on the sense of artistic creation in times of political repression, when the free expression is censored. It is rich in existentialist reflections concerning the uncertain destiny of the people, anonymity, subjugation and submissiveness. The poem was meant to engage all the anonymous 'Josés' - in English he would be translated as John Doe - who go through life without being seen or heard. I included a comparative table of E agora, José? and its translations into English and French in Annex 1.

The translation that was performed during the Zamenhof Day was written by Sartorato (2004, published in Sartorato 2013) and greatly differed from the source text. I inserted it in Annex 2, together with its English translation proposed by me. If we compare the two English versions comprised in Annex 1 and Annex 2, the dissemblance is striking. The second one was actually adapted to the Esperanto target culture, presenting a scenario in the near future in which an Earth government takes power over all peoples and imposes a single language. The 'José' is replaced with the Esperantist who is left without movement, without the right to speak and to write in Esperanto, without Esperanto congresses, libraries and Belles Lettres contests. 'José' is translated in the Esperanto version as 'samideano', a problematic word to translate in ethnic languages ${ }^{5}$. Kaj nun, samideano? is as such an illustrative example of cultural appropriation. What the translator did here was not to translate the literal content but the aesthetic force and the intention of the original poem: in an Esperanto keynote, he calls for commitment and militantism. This dramatic imperative is enhanced by freely chosen title and by the prologue: Sartorato entitles his poem 'Inkubo', 'incubus' or 'nightmare', and takes the liberty of adding an introductory script that acts like stage directions, depicting a plot of a world where Esperanto is forbidden by the autocratic regime. As a whole, the poem is reminiscent of several works thematising militantism in Esperanto.

Addressing the question as to why it has been opted for an adapted version, it is clear that Drummond's poem corresponds to an outdated political configuration and to a different cultural context. The Esperanto translator retrieves the dissidence within it and provides it with social significance for the Esperanto movement. The expressive

I addressed the use of this term in my master thesis (Burghelea 2016), when dealing with the ideological proposal of Esperanto. Some Esperantists choose to address each other by 'samideano', whose etymology suggests a community of thought ( 'sam ', 'same', 'ideo', 'idea', and 'ano', 'person' $\rightarrow$ person who has the same ideas, like-minded). 'Samideano' can be translated in German as 'Gleichgesinnter', in English as 'fellow-idealist', in Portuguese as 'correligionário' or 'coidealista', and in French, through approximate paraphrases, as 'partisan de la même doctrine', 'personne poursuivant les mêmes objectifs'. The term may be used as a traditional appellative among Esperantists, being more commonly used in Brazilian Esperanto discourse and literature (e.g. Sartorato 2013, Saluton, samideano!). In the translation of Inkubo that I propose, I opted to translate 'samideano' by 'Esperantist', given their near-synonymy in Esperanto usage. 
power of this translation lies not in a faithfull reproduction of the original meaning, but in rendering the illocutionary force of its rhythm. The social function of this poem, as revealed through the culturally-embedded translation, is to make the audience actively enagage in the movement. In the end, it comes down to Meschonnic's idea (2007) of translating what the text does, not what the text says. It also corroborates with Gadamer's 'fusion of horizons' (1997), which states that text's horizons depend on the cultural environment, past experience and present interest. Applied to translation, this is reflected in how the translator projected his present horizons and creative interpretation onto the source text. In a changed cultural context, the text consequently underwent a process of meaning-shifting.

\section{What to translate?}

Esperanto translation is also defined by the topics selected. The elective affinities reflect certain aesthetic tastes and ethics of content (Pym 1997). So what do Esperantists translate, and what does this reveal with respect to the ethos of the community?

First of all, we should state that the thematics of the translated literature greatly vary depending on local cultural context. For example, the specificity of an Esperanto library will not be the same in France and Brazil. A French Esperanto library will largely cover thematics of linguistic democracy and linguistic citizenship in a European context; Esperanto will be thus advocated as 'la langue internationale équitable', 'equity' being a term dear to the French discourse. While these ideas are also found in Brazilian Esperanto literature, the prevalence will be for Esperanto's connection to a citizenship of a different order: cosmic or universal. That is due to the fact that in Brazil Esperanto is strongly connected to spiritism, a philosophy-religion postulating the possibility of mediumship and considering Esperanto the proper language for the communication with the spirits; spiritism has hence cleared the way for Esperanto in Brazil, causing Brazilian Esperanto translated literature to be mainly composed of spiritist works and inflecting it with a messianist devotion to the Esperanto cause ${ }^{6}$.

Diachronic evolution is also distinguishable. While the political perspectives of most of the early Esperanto translators were rooted in anarchism, much recent Esperanto translation has tried to adapt to the new discourses placed under the aegis of internationalism and alternative thinking. The language proved to be a functional conveyor of ideology, according to the various horizons of the zeitgeist.

For a full acount of the actual thematical structure of translations in Esperanto, one should examine the book catalogues of the various Esperanto associations. Given

$6 \quad$ For the intertwining between Esperanto and spiritism, see Pardue (2001), Żelazny (2001) and Chaigneau (1908); also, the Lorenz Publishing Association (Spiritisma Eldona Asocio F. V. Lorenz), who spreads through their works Esperanto among spiritists and spiritism among Esperantists. 
the limits of the present paper, I chose to refer to the catalogue of SAT (Sennacieca Asocio Tutmonda - World Anational Association) and to focus on translated poetry. The initial 'Poemtradukoj' page of SAT-Kulturo ( Table 3) encompasses works that we can group under several themes: fight and sacrifice for freedom ('Haĝi Dimitro', 'Killed for humanity', 'Lower the flag!'), capitalism ('Capital', 'Lenka'), pacifism ('To you, crying children of peace, start resisting', 'I aspire to certain day'), love poems ('The Roses are silent', 'Your name'), fairy tales ('I know all the fairy tales'). We see hence that translations into Esperanto abound with ideological and political resonances, advocating for militantism while at the same time ushering in a world free of war.

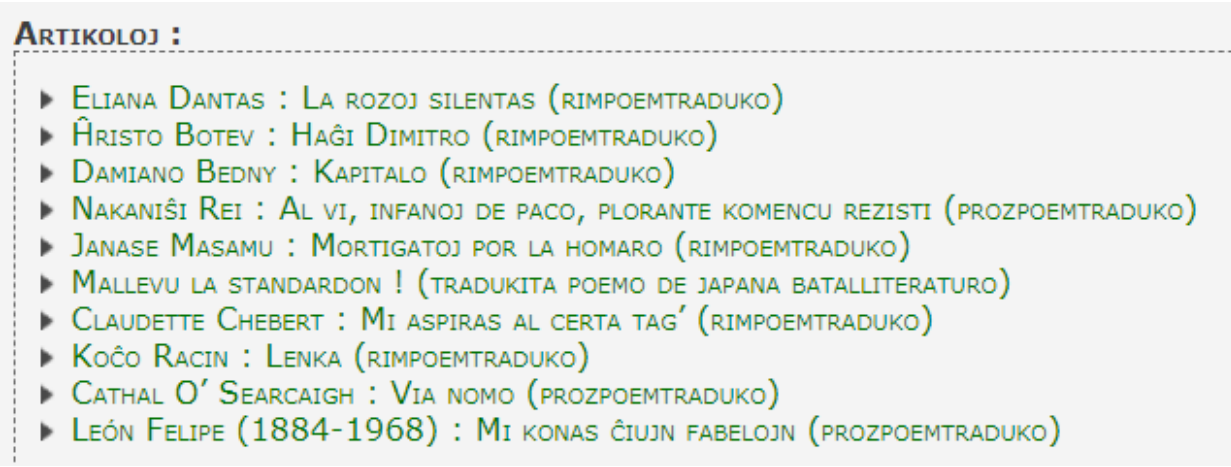

Table 3: Translated poems at SAT Esperanto (http://www.satesperanto.org/spip.php?rubrique32).

\section{The challenge of automatic translation}

Lastly, we will take a close look at the intersection between Esperanto and machine translations. We will analyse the computed and linguistic challenges of machine translation devices. This is essential in understanding how the language is instrumentalised for purposes of illustration. In other words, by showcasing the functioning of Esperanto in computational linguistics, Esperantists often aim at emphasising its virtues as a regularly structured language.

Fully automatic translation is considered an utopian project for now because of the extralinguistic knowledge required in interpretation, yet the challenge of a human-aided machine translation encouraged researchers to look for alternative translation pathways. One of the proposed methods is the use of a simple interlingua as an interface in order to enhance software performance. Using Esperanto as a pivot-language in translation machines is strongly enhanced by Esperantists, due to the language's lack of grammatical ambiguities and its capacity of reducing language pairs. Schubert (1992) argues for the use of Esperanto as an intermediate language, based on its precision and expres- 
siveness. Boddington (2004) suggests this method results in high accuracy translation. For Gobbo (2015), Esperanto and machine translations are two responses to the same question of the myth of Babel.

Many studies have investigated the feasability of translating through interlingua machine mechanisms. Esperanto was used in slightly modified versions as an intermediate language by the Distributed Language Technology project (in the 1980s), by the Universal Translation Language machine translation programme (1999) and by the open source project Apertium (2005).

A further translation software attempt was Esperus (Orlova 2015), meant to translate from Esperanto to Russian using a Moses toolkit. Using a statistical machine translation system, such software requires numerous phrase tables, also called parallel data or bitext. While the ideal data for the toolkit is considered to be documents written in a standardized language such as political texts, this could not be put into practice with Esperanto, given that Esperano is not an official language, not being regularly used by any government. Therefore, the parallel phrases were looked for in Esperanto literature, more exactely in fiction novels of Russian authors translated into Esperanto, including Nikolaj Gogol, Ivan Turgenev and Mikhail Bulgakov. Using these parallel corpora, the software enabled translation of new phrases from Esperanto to Russian. Several problems were discovered, including formal and informal address, and different of writing diacritics in Esperanto. The study stressed however that the results were better than those provided by Google Translator, which uses English as an interlingua.

Other Esperanto-based softwares developed for helping automatic translation and correction include: Esperantilo (2008), Lingvohelpilo (2009), Lingvoilo (2015) - '-ilo' being the Esperanto suffix for 'tool'.

The outcomes of such studies advocate in the end for the use of Esperanto in machine translation. They are part of a transversal approach aiming at the defence and illustration of the Esperanto language $\mathrm{e}^{7}$.

\section{Final remarks}

Travelling from clasic literature to machine translation, we see that translating into Esperanto takes various purpose-oriented forms. The creativity employed in this process is a consequence of Esperanto's status of in-between language, situated in what Bhabha calls 'the third space'. It is an example of textual metissage as defined by Nouss. While

7 Many other studies, usually carried out by Esperantists, promote the propaedeutic value of Esperanto in learning foreign languages, Esperanto's potential in international communication, Esperanto's possible virtues as an international auxiliary language in medicine, etc. While objective results in favour of the advantages of Esperanto have been achieved, the dissemination of these results and the presentation of the language in general take often the form of a declaration of love to Esperanto, 'the language of cherubs'. 
performing the mediatory function, Esperanto translation plays a role of ideological gate-keeper, conveying Esperantist ideas of changing the world for the better through activism and through an ethnically neutral, equitable language.

On a final note, we can conclude that translation goes beyond linguistics towards cultural encounters and computing challenges. Through translation, Esperanto culture mirrors ethnic cultures and illustrates itself as a valuable multipurpose resource. Esperantists appropriate texts worth translating, proceed sometimes at a reconfiguration of their meaning and come up with creative references that are operative within the cultural Esperanto framework. Moreover, they contruct fictitious versions of Esperanto to fill sociolectal gaps in literature. They reflect and at the same time inform the ethos of the community. This partakes of the aesthetic and poetic issues of translation. Therefore, translators play a key role in the construction of the Esperanto cultural identity.

\section{Bibliography}

Auld, W. 1997: La enigmo pri Hamleto. In: Pajleroj kaj stoploj. Rotterdam: Universala EsperantoAsocio.

Benjamin, W. 1992 [1923]: The Task of the Translator. In: Schulte, R. \& Biguenet, J.: Theories of Translation. Chicago: University of Chicago Press.

Bhabha, H. 1994: The Location of Culture. London: Routledge.

Boddington, R. 2004: Evaluation of an Esperanto-Based Interlingua Multilingual Survey Form Machine Translation Mechanism Incorporating a Sublanguage Translation Methodology. Edith Cowan University, Thesis.

Buden, B. \& Nowotny, S. 2009: Cultural Translation: An Introduction to the Problem. In: Translation Studies $2 / 2$.

Burghelea, M. 2016: L'espéranto, entre idéaux universels et pratiques culturelles locales. Les cas français, belge et brésilien. Master thesis in Intercultural Mediation. Université de Lille 3.

Chaigneau, C. 1908: L'Espéranto et le spiritisme. In: La Revue scientifique et morale du spiritisme, Paris.

Chaves, S. 1986: La estonto dependas de ni. Rio de Janeiro: Internacia Jaro de Paco.

Cheung, M. 2014: Translation as Intercultural Communication: Views from the Chinese Discourse on Translation. In Bermann, S. \& Porter, C. (Eds.): A companion to translation studies. Chichester: Wiley-Blackwell.

Coste, D. 2016: The Poetics and Politics of Literary Translation. University of Pittsburgh, colloquium paper.

De Man, P. 1986: Conclusions: Walter Benjamin's 'The Task of the Translator': The Resistance to Theory. Minneapolis: University of Minnesota Press.

Derrida, J. 1985: Des Tours de Babel. In: Graham, J. F. (ed.): Difference in Translation. Ithaca and London: Cornell University Press.

Gadamer, H. G. 1997: Truth and Method. New York: Continuum.

Gobbo, F. 2015: Machine Translation as a complex system, and the phenomenon of Esperanto. In: Interdisciplinary Description of Complex Systems, 13/2.

Halvelik, M. 1969: Arcaicam Esperantom. Brugge: Eldonejo-librejo Sonorilo. 
Halvelik, M. 1989: Planing nonstandard language. In Schubert, K. \& Maxwell, D.: Interlinguistics, aspects of the Science of Planned Languages. Trends in Linguistics: Studies and monographs 42. Berlin: Mouton De Gruyter.

Janton, P. 1992: Esperanto: Language, Literature, and Community. Albany: State University of New York Press.

Janton, P. 1989: If Shakespeare had written in Esperanto... Aesthetic criteria in an artificial language. In: Schubert, K.: Interlinguistics: Aspects of the Science of Planned Languages. Berlin, New York: Mouton de Gruyter.

Kalocsay, K. 1931: Lingvo Stilo Formo. Budapest: Literatura Mondo.

Meschonnic, H. 1995: Politique du rythme, politique du sujet. Paris: Verdier.

Meschonnic, H. 1999: Poétique du traduire. Paris: Verdier.

Meschonnic, H. 2007: Éthique et politique du traduire. Paris: Verdier.

Nouss, A. 2005: Translation and Metissage. In: St-Pierre, P. \& Karr, P.C. (Eds): Translation. Reflections, Refractions, Transformations. Delhi: Pencraft International.

Orlova, D. 2015: Esperus: the First Step to Build a Statistical Machine. Translation System for Esperanto and Russian Languages. Saint Petersburg State University. Paper presented at the AINL-ISMW Fruct conference.

Pardue, D. 2001: Uma só língua, uma só bandeira, um só pastor: Spiritism and Esperanto in Brazil. In : Esperantologio / Esperanto Studies 2.

Pym, A. 1997: Pour une éthique du traducteur. Arras: Artois Presses Université, Presses de l'Université d'Ottawa.

Pym, A. 2001: Introduction: The return to ethics in translation studies. In The Translator, Special Issue The Return to Ethics, 2001, 7(2).

Sartorato, A. 2013: Saluton, samideano! Rio de Janeiro: Editora KKE.

Schubert, K. 1989: Interlinguistics - Its Aims, Its Achievements, and Its Place in Language Science. In: Schubert, K. \& Maxwell, D. (Eds): Interlinguistics - Aspects of the Science of Planned Languages (Trends in Linguistics, Studies and Monographs 42). Berlin/New York: Mouton de Gruyter.

Schubert, K. 1992: Esperanto as an intermediate language for machine translation. In: Newton, J. (ed.): Computers in Translation: A Practical Appraisal. London: Routledge.

Spivak, G. C. 1993: The Politics of Translation. In Outside the teaching machine. New York: Routledge.

Spivak, G. C. 1993: Translation as culture. In: St-Pierre, P. \& Kar, P. C.: In translation. Reflections, refractions, transformations. Amsterdam: John Benjamins.

Tonkin, H. \& Esposito Frank, M. 2010: The Translator as Mediator of Cultures. Philadelphia: John Benjamins Publishing.

Tonkin, H. 2016: Zamenhof kaj Shakespeare. In: La Ondo de Esperanto, 2016/4-5.

Venuti, L. 1995: The Translator's Invisibility. London and New York: Routledge.

Vermeer, H. J. 1996: A Skopos theory of translation: Some arguments for and against. Heidelberg: Textcontext.

Zelazny, W. 2001: Les idées sociales et réligieuses suscitées par le phénomène des langues dites artificielles (aspect interlinguistique et social). In Esperantologio/Esperantic Studies

SAT catalogue of translated poetry, URL: http://www.satesperanto.org/spip.php?rubrique32

\section{Comics text and image samples}

Hergé 1958: Tintin au Tibet. In Le Journal de Tintin, Bruxelles, Le Lombard.

Hergé 1962: Tintin in Tibet. Translated by Lonsdale-Cooper, L. \& Turner, M. Publisher: Methuen $\&$ Co.

Hergé 2005: Tinçjo en Tibeto. Translated by Gonin, H. Publisher: Casterman. 


\section{Annex 1}

José. Written by Carlos Drummond de Andrade (https://www.culturagenial.com/poema-e-agora-josecarlos-drummond-de-andrade/)

What about now, José? Translated by Paulo Diniz (https://lyricstranslate.com/en/e-agora-josé-whatabout-now-josé.html)

José Translated by Pascal Maillard (http://pascalmaillard.over-blog.com/pages/CARLOS_DRUMMOND_DE_ANDRADE-1291580.html)

José

E agora, José?

A festa acabou,

a luz apagou,

o povo sumiu,

a noite esfriou,

e agora, José?

e agora, você?

você que é sem nome, que zomba dos outros, você que faz versos, que ama, protesta? e agora, José?

Está sem mulher, está sem discurso, está sem carinho, já não pode beber, já não pode fumar, cuspir já não pode, a noite esfriou, o dia não veio, o bonde não veio, o riso não veio, não veio a utopia e tudo acabou e tudo fugiu e tudo mofou, e agora, José?

E agora, José?

Sua doce palavra, seu instante de febre, sua gula e jejum, sua biblioteca, sua lavra de ouro, seu terno de vidro, sua incoerência, seu ódio - e agora?
What about now, José?

What about now, José?

The party is over,

the light is off,

the people are gone,

the night's gone cold,

what about now, José?

what about now, you?

you, who are nameless

you, who mocks others,

you, who writes verses,

who loves, protests?

what about now, José?

You have no wife,

Have no love,

no speech,

can no longer drink,

can no longer smoke,

spit no longer,

night's gone cold,

dawn hasn't come

tram hasn't come,

laughter hasn't come,

utopia has come not

and everything's over

everything fleed,

everything wilted,

what about now, José?

Your sweet word, your moment of fever, your glutony and fast, your library,

your gold plating,

your glass suit, your contradiction, your hatred - what about now?
José

Et maintenant, José ?

La fête est finie,

La lumière est éteinte,

Les gens sont partis,

La nuit s'est refroidie,

Et maintenant, José?

Et maintenant, José ?

Toi qui es sans nom

Qui te moque de autres,

Toi qui écris des vers,

Qui aimes, tu protestes?

Et maintenant, José ?

Tu es sans femme,

Tu es sans discours,

Tu es sans caresse,

Tu ne peux déjà pas boire,

Tu ne peux déjà pas fumer,

Cracher déjà tu ne peux,

La nuit s'est refroidie,

Le jour n'est pas venu,

Le tram n'est pas venu,

Le rire n'est pas venu,

N'est pas venu l'utopie

Et tout est fini

Et tout a fui

Et tout a pourri,

Et maintenant, José?

Et maintenant, José ?

Sa belle parole,

Son instant de fièvre,

Sa gourmandise et son jeun,

Sa bibliothèque,

Son labeur d'or,

Son costume de verre,

Son incohérence,

Sa haine - Et maintenant? 
Com a chave na mão quer abrir a porta, não existe porta; quer morrer no mar, mas o mar secou; quer ir para Minas, Minas não há mais. José, e agora?

Se você gritasse, se você gemesse, se você tocasse a valsa vienense, se você dormisse, se você cansasse, se você morresse... Mas você não morre, você é duro, José!

Sozinho no escuro qual bicho-do-mato, sem teogonia, sem parede nua para se encostar, sem cavalo preto que fuja a galope, você marcha, José! José, para onde?
Having the key in your hands, wants to open the door, there's no door; wants to drown in the sea, but the sea has dried; wants to go to Minas, Minas there are no longer. José, what about now?

If you screamed, if you moaned, if you played Viena's waltz, if you slept, if you got tired, if you died, But you don't die, you are tough, José!

Alone in the dark, as a wild animal, without theogony, without naked wall to lie on, without dark horse, shall it runaway, You march, José! José, where to?
Avec la clé dans la main

Tu veux ouvrir la porte,

Il n'existe pas de porte;

Tu veux mourir dans la mer

Mais la mer s'est asséchée;

Tu veux aller dans le Minas,

Minas il n'y a plus.

Et maintenant, José?

Si tu cries,

Si tu gémis,

Si tu touches

La valse viennoise,

Si tu dors,

Si tu fatigues,

Si tu meurs...

Mais tu ne meurs pas,

Tu es dur, José!

Seul dans l'obscur

Tel l'animal des bois

Sans théogonie,

Sans mur nu

Pour s'adosser,

Sans cheval noir

Qui fuit au galop,

Tu marches, José!

José, où vas-tu?

\section{Annex 2}

Inkubo

Aloísio Sartorato. Apud Sartorato 2013.

Prologo

Iam en ne tro fora estonteco. Autokrata registaro estras la tutan planedon. Iu nacia lingvo fariĝis la oficiala lingvo de la Tero. La disvastigado, instruado kaj uzado de Esperanto estis lauleĝe malpermesita.
Kaj nun, samidean'?
La songo finiĝis
movad' estingiĝis
popol' malaperis,
la lingvo ŝtoniĝis.
kaj nun, samidean'?
kaj nun, samidean'?
kaj nune, samidean'?
kaj nune, vi mem?
Vi mem, esperantano
vi mem, movadano,
aganto, batalanto
kaj nun, samideano?

\section{Nightmare}

(my translation)

Prologue

Somewhere in a not-so-distant future. An autocratic governement rules the whole planet. A national language became the official language of the Earth. The spreading, teaching and using of Esperanto are forbidden according to the law.

What about now, Esperantist?

The dream is over, the movement is extinguished, the people disappeared, the language is petrified, what about now, Esperantist? what about now, Esperantist? what about now, Esperantist? what about now, you? you, Esperanto speaker, you, member of the movement, activist, combatant, what about now, Esperantist? 
Jen vi, sen movado

jen vi, sen kongreso

kaj sen parolado.

Jam ne povas plu informi,

jam ne povas plu instrui

eĉ kunveni ne povas.

Jen - falis la nokto!

La venko ne venis,

restis nur la utopi'.

Kaj nun, samidean'?

Kaj nun, samidean'?

Via saĝa parolo,

via senlaca laboro,

entuziasmo kaj bravo.

Via biblioteko,

via arda verkemo, via Belarta Konkurso, via amo al la Majstro, al homar' - kaj nun?

Vi lingvon scipovas por transdoni al homar', sed ne plu estas homar'; pro movad' volas morti, sed finiĝis movad'; volas iri al Kongres' sed ne plu estas Kongres'! Samidean', kaj nun?

Se vi povus krii, se vi povus gemi, se vi povus plori, se vi povus dormi, se vi povus morti. Tamen vi ne mortas, vi rezistas, samidean'!

Sola, en malhela arbar', sen Esperantio

kaj diligenta kolegar', sen movado verda

kaj geamika fratar' por apogi vin, vi rezistas, samidean', sed, samidean', gis kiam???
Here you are with no movement, Here you are with no congress and with no speech.

You can no longer inform, you can no longer teach, you can not even meet.

Night has come!

Victory hasn't come, only utopia is left.

What about now, Esperantist?

What about now, Esperantist?

Your wise word,

your tireless work,

enthousiasm and bravery.

Your library,

your ardent writing desire, your Belles Lettres contest, your love for Zamenhof, for the humanity - what about now?

You know one language, to give to the humanity, but there's no humanity; want to die for the movement, but the movement is over; want to go to the Congress, but there is no longer Congress. Esperantist, what about now?

If you could scream, if you could groan, if you could cry, if you could sleep, if you could die.

But you don't die, you withstand, Esperantist!

Alone in the dark wood, with no Esperantio, with no hardworking team, with no green movement and friendly brotherhood to lie on, You withstand, Esperantist! But, Esperantist, till when??? 